\title{
THE EFFICACY OF VITAMIN C INFUSION IN REDUCING POST- INTUBATION SORE THROAT
}

\author{
Mohammad Hossein Jarahzadeh', Mohammad Hossein Mousavi Biokil, Hamidreza Abbasi' ${ }^{1}$, \\ Mohammad Ali Jafari², Elnaz Sheikhpour ${ }^{3}$ \\ ${ }^{1}$ Department of Anesthesiology, Shahid Sadoughi University of Medical Sciences, Yazd, Iran \\ 2Department of Emergency Medicine, Shahid Sadoughi University of Medical Sciences, Yazd, Iran \\ ${ }^{3}$ Hematology and Oncology Research Center, Shahid Sadoughi Hospital, Shahid Sadoughi University of Medical Sciences, \\ Yazd, Iran
}

\section{EFIKASNOST INFUZIJE VITAMINA C U SMANJIVANJU UPALE GRLA POSLE INTUBACIJE}

\author{
Muhamed Husein Džarazade', Muhamed Husein Mosuvai Biokil, Hamidreza Abasil, \\ Muhamed Ali Džafari², Elnaz Šeikpur 3 \\ ${ }^{1}$ Klinika za anesteziologiju, Šahid Sadugi Univerzitet medicinskih nauka,Jazd, Iran \\ 2 Urgentni centar, Šahid Sadugi Univerzitet medicinskih nauka, Jazd, Iran \\ ${ }^{3}$ Centar za istraživanja u oblasti hematologije i onkologije, Šahid Sadugi bolnica, Šahid Sadugi Univerzitet medicinskih \\ nauka, Jazd, Iran
}

\begin{abstract}
Objective. Vitamin $C$ may be a beneficial adjunct for decreasing sore throat following tracheal intubation. Therefore, the aim of this study was to evaluate the effect of vitamin $C$ infusion on post-intubation sore throat reduction.

Methods. This double-blind randomized study was conducted on 70 patients undergoing elective laparoscopic surgery in Shahid Sadoughi Hospital. The patients were allocated into two groups (experimental and control). All patients received $2 \mathrm{mg}$ midazolam and 100 microgram fentanyl citrate premedication. Thirty minutes after induction of anesthesia, $5 \mathrm{mg}$ morphine was given to all patients. In the next step, the experimental group received vitamin $C$ (2 g) mixed with normal saline for the total injection volume of $500 \mathrm{~mL}$ during $30 \mathrm{~min}$ and those in control group received normal saline without vitamin $C$.
\end{abstract}

Results. In current study, no remarkable difference was observed between the experimental and control groups, considering age, sex and BMI ( $p>0.05)$. Significant difference was observed between the experimental and control groups in terms of postoperative sore throat at specified time including 1, 6 and 24 hours. A significant difference was noticed between experimental and control groups with respect to postoperative pain score at specified time $(p<0.05)$. However, no difference was seen between the experimental and control groups regarding postoperative nausea, vomiting and itchy throat ( $p>0.05)$.

Conclusion. According to the results of this study, the use of vitamin $C$ reduced the incidence of sore throat and pain score in patients undergoing laparoscopic surgery. It seems that vitamin $C$ can decrease morphine indicated for postoperative pain.

Key words: intubation, intratracheal; pharyngitis; ascorbic acid

\section{SAŽETAK}

Cilj. Vitamin C može biti korisno sredstvo za smanjenje upale grla posle endotrahealne intubacije. Zbog toga je cilj ove studije bio da se proceni efekat infuzije vitamina $C$ na smanjivanje upale grla posle intubacije.

Metode. Ova dvostruko-slepa randomizovana studija sprovedena je na 70 pacijenata koji su bili podvrgnuti elektivnoj laparoskopskoj operaciji u bolnici Šahid Sadugi. Pacijenti su raspoređeni $u$ dve grupe (eksperimentalna $i$ kontrolna). Svi pacijenti su primili medikaciju u vidu midazolama od 2 mg i 100 mikrograma fentanil citrata. Trideset minuta nakon indukcije anestezije, svim pacijentima je ordinirano $5 \mathrm{mg}$ morfijuma. U sledecem koraku, pacijenti $u$ eksperimentalnoj grupi su primili $2 \mathrm{~g}$ vitamina $C$, pomešanog sa normalnim fiziološkim rastvorom ukupne zapremine $500 \mathrm{ml}$ tokom 30 minuta, a pacijenti u kontrolnoj grupi su dobili normalan fiziološki rastvor bez vitamina $C$.

Rezultati. U našoj studiji nije primećena značajna razlika između eksperimentalne $i$ kontrolne grupe, imajuci $u$ vidu starost, pol i BMI (p>0,05). Primećena je značajna razlika između ove dve grupe u pogledu postoperativne upale grla $u$ određenom vremenu, uključujući 1, 6 i 24 sata. Značajna razlika primećena je između grupa u odnosu na postoperativni bol izmeren skalom i to u određenom vremenu $(p<0,05)$. Međutim, nije primećena razlika između eksperimentalne $i$ kontrolne grupe u pogledu postoperativne mučnine, povraćanja i svraba u grlu $(p>0,05)$.

Zaključak. Rezultati ove studije ukazuju da je upotreba vitamina C smanjila učestalost upale grla i bola koji je meren skalom, kod pacijenata koji su bili podvrgnuti laparoskopskoj operaciji. Čini se da vitamin C može smanjiti upotrebu morfijuma kod postoperativnog bola.

Ključne reči: intubacija, endotrahealna; faringitis; askorbinska kiselina 


\section{INTRODUCTION}

In spite of development of anaesthetic techniques, sore throat following endotracheal intubation is the most frequent adverse side effect of anaesthesia (1-19). Sore throat is associated with stress, unpleasant feelings, dissatisfaction and morbidity (20). The sore throat incidence varies from $14.4 \%$ to $50 \%$ after tracheal intubation and $5.8 \%$ to $34 \%$ after laryngeal mask insertion (21). The etiology of disease is related to factors including sex, age, smoking, intubation factors such as duration (21), intra-operative tube movement $(2,23)$, tube size $(2$, $24)$, intracuff pressure (2,24), cuff design (23) and suctioning. In addition, the type of surgery and study population are other important causative factors (20). The sore throat complication includes mucosal erosion caused by the cuff of the tracheal tube, mucosal dehydration and trauma from tracheal intubation (25). Several studies in developed and Western populations have been done to prevent postoperative sore throat (26). On the other hand, pharmacological and non-pharmacological procedures are used for the elimination of sore throat (27). Therefore, decreasing and minimizing postoperative sore throat is the main goal (28).

It has been obviously demonstrated that using a smaller tracheal tube decreases sore throat incidence likely due to reduced pressure at the tube-mucosal interface (Mc). Modern and new anaesthesia practices and improved airway tools have decreased these complications (25). Opioids as the most widely used class of analgesics have been used in management of postoperative pain, but they may increase the risk of nausea and vomiting and postpone postsurgical recovery of gastrointestinal mobility (28). New, non-opioid analgesic alternatives have been recommended for decreasing pain and restricting opioid-related side effects (29). However, these nonsteroidal drugs have side effects of their own (30). Vitamin $\mathrm{C}$ is a medication with virtually no side effects and complications (30). It as a water-soluble vitamin with neuroprotective, and neuromodulating properties $(31,32)$. Vitamin $\mathrm{C}$ also demonstrates anti-inflammatory characteristics and decreases inflammation including proinflammatory cytokines, C-reactive protein, interleukins and tumor necrosis factor-alpha. It is also considered as a necessary micronutrient that acts as a cofactor in several chemical and enzymatic pathways (33). The accurate mechanism of analgesic effect of vitamin $\mathrm{C}$ is not well understood. It acts an antioxidant and inhibits reactive oxygen species (ROS) formation. Vitamin C deficiency is rare in population of developed countries, with prevalence in United States of about 6\% $(34,35)$. Diseases such as surgery and trauma lead to depletion of vitamin $\mathrm{C}$ in body (36). Infection, sepsis (37), cancer and colon surgery (28) are other diseases which are associated with vitamin $\mathrm{C}$ deficiency. Recent studies have shown that vitamin C may be effective in reducing post-operative pain especially in chronic and acute pain following orthopedic surgeries (30). Jeon et al., also confirmed a previous study and reported that vitamin $\mathrm{C}$ might be a beneficial adjunct for management of pain without main side effects (28). Carr et al., also demonstrated the effect of vitamin $\mathrm{C}$ on the incidence of complex regional pain syndrome in ankle and wrist surgery (34). Since the role of vitamin C in reducing sore throat after intubation is not specified, the aim of this study was to evaluate the efficacy of vitamin $\mathrm{C}$ infusion in reducing sore throat after intubation.

\section{PATIENTS AND METHODS}

This double-blind randomized study was conducted on 70 patients (age range: 20-60 years old) undergoing elective laparoscopic surgery in Shahid Sadoughi Hospital, Yazd, Iran during the period from June 2016 to September 2017. Written consents were taken from the patients and the study was approved by the ethic committee of Shahid Sadoughi University of Medical Sciences. Demographic data including age, body mass index (BMI), sex and clinical data were extracted from medical records.

Patients undergoing elective laparoscopic surgery with ASA1 and ASA2 from 2016 to September 2017 were entered into the study. However, the patients with a history of sore throat, voice violations, throat and laryngeal disease, cardiovascular disease, addiction and sensitization were excluded from the study. Moreover, if the duration of the patient's intubation was more than 2 hours, or if the intubation was done more than once, there was traumatic throat and Larynx injury during intubation, these patients were excluded from the study.

The patients were allocated into two groups ( $\mathrm{n}=35$ ). All patients received $2 \mathrm{mg}$ midazolam and 100 microgram fentanyl citrate premedication. The induction of anesthesia was taken with $2 \mathrm{mg} / \mathrm{kg}$ propofol and $0.5 \mathrm{mg} / \mathrm{kg}$ atracurium. After 3 minutes, the patients underwent mechanical ventilation. In order to maintain anesthesia, propofol infusion $(100-200 \mu \mathrm{g} / \mathrm{kg} / \mathrm{min})$ was used. Thirty minutes after the induction of anesthesia, $5 \mathrm{mg}$ morphine was given to all patients. Then the experimental group received vitamin $\mathrm{C}(2 \mathrm{~g})$ mixed with normal saline for a total injection volume of $500 \mathrm{~mL}$ during 30 minutes and those in the control group received normal saline $500 \mathrm{~mL}$ without vitamin C. Patients were extubated following the end of surgery.

Parameters including severity of sore throat, pain, nausea, vomiting, itchy throat, sore throat and severity of sore throat were measured at 1,6 , and 24 hours after entering the recovery and recorded in a questionnaire. The visual analog scale (VAS) measured acute and chronic pain. 
After completion of the study, data were entered into SPSS version 21. Tests such as Mann-Whitney test, Chisquare test and independent t-test were used for analysis of data. $\mathrm{P}$-value $<0.05$ was considered statistically significant.

\section{RESULTS}

In the current study, $45.7 \%$ and $51.4 \%$ of patients in experimental and control group were men, respectively. Demographic properties of patients showed no remarkable difference between the experimental and control groups. The mean age ( \pm standard deviation) in the control and the experimental group was $39.91 \pm 12.78$ and $41.4 \pm 12.2$ years, respectively ( $\mathrm{t}$-test, $\mathrm{p}=0.618$ ). The mean body mass index (BMI) in the control and the experimental group was $22.43 \pm 3.1$ and $22.26 \pm 2.55 \mathrm{~kg} / \mathrm{m} 2$ (t-test, $\mathrm{p}=0.800$ ).

The frequency of complications in patients undergoing elective laparoscopic surgery is shown in Table 1 . There are a significant difference was observed between experimental and control groups in terms of postoperative sore throat at specified time including 1, 6 and 24 hours $(\mathrm{p}<0.01)$. However, no significant difference was seen between experimental and control groups in terms of postoperative nausea, vomiting and itchy throat ( $p>0.05)$.

There are significant differences between the experimental and the control groups considering postoperative pain scores. The mean scores $( \pm$ standard deviations) at 1 hour were $2.09 \pm 2.44$ and $3.54 \pm 2.44$ $(\mathrm{p}=0.011)$, at 6 hours $1.66 \pm 1.84$ and $3.34 \pm 2.04(\mathrm{p}=0.001)$ and at 24 hours $1.11 \pm 0.57$ and $1.61 \pm 1.6(\mathrm{p}=0.001)$, for the experimental and the control groups, respectively.

\section{DISCUSSION}

Administration of vitamin $\mathrm{C}$ infusion in patients undergoing laparoscopic surgery showed that sore throat and score pain decreased compared to the control group. Vitamin $\mathrm{C}$ has a neuromodulating action (38), particularly dopamine and glutamate mediated neurotransmission (28). Laparoscopic colectomy leads to oxidative stress and ROS formation which contributes to abdominal inflation/deflation. Increased ROS and decreased pre and postoperative level of vitamin $\mathrm{C}$ can be compensated by supplementation such as vitamin $\mathrm{C}$.

Jeon et al., evaluated the effect of Vitamin $\mathrm{C}$ on postoperative pain after Laparoscopic Colectomy. This study was conducted on 100 patients undergoing laparoscopic colectomy (28). One group of these patients received $50 \mathrm{mg} / \mathrm{kg}$ vitamin $\mathrm{C}$ and the other group received placebo. The findings showed that the patients who received vitamin $\mathrm{C}$ had higher level of this vitamin in plasma than the control group and needed less morphine, however no significant difference was seen between these two groups in terms of side effects, fatigue score, or pain score during cough. Therefore, according to these findings, high dose of vitamin $\mathrm{C}$ infusion reduced postoperative pain during the first 24 hours which is consistent with our study. Moreover, Jeon et al., reported that vitamin $\mathrm{C}$ decreases consumption of morphine in the early periods of postoperative period. It seems that higher dose of vitamin $\mathrm{C}$ with longer time of infusion may be essential to retain enough vitamin concentration and hold analgesic effects (28). Kanazi et al. evaluated the effect of vitamin $\mathrm{C}$ on using of morphine after laparoscopic cholecystectomy. They selected 80 patients and allocated

Table 1. Frequency of complications in patients undergoing elective laparoscopic surgery

\begin{tabular}{|l|c|c|c|}
\hline Parameters & Experimental & Control & p-value \\
\hline Sore throat 1 hour after surgery & $17(48.6)$ & $28(80)$ & 0.006 \\
\hline Sore throat 6 hour after surgery & $18(51.4)$ & $22(82.9)$ & 0.005 \\
\hline Sore throat 24 hours after surgery & $8(22.9)$ & $24(68.6)$ & $<0.001$ \\
\hline Nausea 1 hour after surgery & $7(20)$ & $12(34.3)$ & 0.182 \\
\hline Nausea 6 hour after surgery & $15(42.9)$ & $13(37.1)$ & 0.628 \\
\hline Nausea 24 hours after surgery & $6(17.1)$ & $8(22.9)$ & 0.553 \\
\hline Vomiting 1 hour after surgery & $3(8.6)$ & $2(5.7)$ & 0.643 \\
\hline Vomiting 6 hour after surgery & $2(5.7)$ & $5(14.3)$ & 0.235 \\
\hline Vomiting 24 hours after surgery & $1(2.9)$ & $2(5.7)$ & 0.558 \\
\hline Itchy throat 1 hour after surgery & $1(2.9)$ & $0(0)$ & n.a. \\
\hline Itchy throat 6 hour after surgery & $3(8.6)$ & $4(11.4)$ & 0.690 \\
\hline Itchy throat 24 hours after surgery & $1(2.9)$ & $1(2.9)$ & 1 \\
\hline
\end{tabular}

numbers represent absolute values (percentage); n.a.-not applicable 
them to 2 groups. One group consumed $2 \mathrm{~g}$ vitamin $\mathrm{C}$ and other group placebo before anesthesia induction. Patients were assessed at 2, 4, 6, 12 and 24 hours after surgery. The findings of this study showed that consumption of morphine was lower in the vitamin $\mathrm{C}$ group compared to the placebo group. Moreover, no significant difference was observed between the two groups with respect to pain score or complications. Satisfaction scores were also similar in both groups. Vitamin C (2 g) reduced consumption of morphine in the postoperative period in these patients. Chen et al., in 2016 assessed perioperative vitamin $\mathrm{C}$ on postoperative pain undergoing surgical procedures. They concluded that $2 \mathrm{~g}$ perioperative dose of vitamin $\mathrm{C}$ was useful for decreasing morphine consumption after surgery (39). Another study confirmed previous studies and reported that $2 \mathrm{~g}$ vitamin $\mathrm{C}$ decreases requirement of morphine, non-steroidal antiinflammatory drugs and side effects of patients under laparoscopic cholecystectomy (30). Carr et al. in 2017 reported that administration of vitamin $\mathrm{C}$ in patients with chronic regional pain syndrome reduced these symptoms (37).

In another study, oral dose of vitamin C (2 gr) was administered to patients with randomised cholecystectomy 1 hour before anesthesia. The level of plasma vitamin C was assessed $1 \mathrm{~h}$ post-randomization. The findings showed that the level of this vitamin in vitamin $\mathrm{C}$ group and placebo group were $57 \pm 28$ and $23 \pm 17 \mu \mathrm{mol} / \mathrm{l}$, respectively. Postoperative morphine consumption and pain score were recorded during 24 hours. Morphine consumption in the placebo group was higher than vitamin $\mathrm{C}$ group. However, no significant difference was seen between two groups in terms of pain score (37) which was not consistent with our study. Co- administration of vitamin $\mathrm{C}(1 \mathrm{~g} / \mathrm{kg})$ with morphine inhibited morphine tolerance development and physical dependence in mice (40). Intraperitoneal injection of vitamin C (400 mg/ $\mathrm{kg})$ in rats significantly reduced consumption of morphine and syndrome signs (41). Murata et al., have shown that consumption of opioid drugs has been decreased in patients who received $0.5-3 \mathrm{~g} /$ day vitamin $\mathrm{C}$, while only $17 \%$ of patients who received $5-30$ g/day vitamin $\mathrm{C}$ needed opioids in contrast to $79 \%$ in the control group (34). Vitamin C showed anti-nociceptive effects in mice. In addition, it demonstrated additive and synergistic effects in combination with the opioids morphine and tramadol (42). Therefore, administration of vitamin C seems to have potential application as an adjunctive therapy to reduce opioid need and dependence. Several mechanisms have been suggested for vitamin $\mathrm{C}$ analgesic properties. It participates in the biosynthesis of amidated opioid peptides as a cofactor for peptidyl-glycine $\alpha$ amidatingmonooxygenase, the enzyme to convert carboxy terminal residue of neuropeptides and peptide hormones to amidate (37). Vitamin C also participates for biosynthesis of norepinephrine, release of noradrenaline and acetylcholine from synaptic vesicles (43). These neurotransmitters are an important component of the inhibitory pain way (44). Carr et al., reported that vitamin $\mathrm{C}$ affects up regulation or down regulation of specific gene by regulating epigenetic markers and transcription factors (34).

In conclusion, the use of vitamin $\mathrm{C}$ reduced the incidence of sore throat and pain score in patients undergoing elective laparoscopic surgery. It seems that vitamin $\mathrm{C}$ can decrease morphine indicated for postoperative pain. Therefore, vitamin $\mathrm{C}$ is considered as effective and efficient adjunctive therapy for decreasing pain. It is proposed that vitamin $\mathrm{C}$ infusions administered to patients undergoing elective laparoscopic surgery.

\section{REFERENCES}

1. Fuller L. The relationship between preintubation lidocaine and postanesthesia sore throat. AANA J 1992; 60: 374-8.

2. Lee JY. Incidence and risk factors of postoperative sore throat after endotracheal intubation in Korean patients. J IntMed Res 2017; 45. 744-52.

3. Lehmann M, Monte K, Barach P. Postoperative patient complaints: a prospective interview study of 12,276 patients. J ClinAnesth 2010; 22: 13-21.

4. Arts MP, Rettig TC, de Vries J. Maintaining endotracheal tube cuff pressure at $20 \mathrm{~mm} \mathrm{Hg}$ to prevent dysphagia after anterior cervical spine surgery; protocol of a double-blind randomised controlled trial. BMC MusculoskeletDisord 2013; 14: 280-7.

5. El-Boghdadly K, Bailey CR, Wiles MD. Postoperative sore throat: a systematic review. Anaesthesia 2016; 71 : 706-17.

6. $\mathrm{Hu}$ B, Bao R, Wang X, et al. The size of endotracheal tube and sore throat after surgery: a systematic review and meta-analysis. PLoS One 2013; 8: e74467.

7. Orandi A, Orandi A, Najafi A. Postintubation sore throat and menstruation cycles. Anesth Pain Med 2013; 3: 243-9.

8. Christensen AM, Willemoes-Larsen H, Lundby L, et al. Postoperative throat complaints after tracheal intubation. Br J Anaesth 1994; 73: 786-7.

9. Biro P, Seifert B, Pasch T. Complaints of sore throat after tracheal intubation: a prospective evaluation. Eur J Anaesthesiol 2005; 22: 307-11.

10. Inoue S, Abe R, Tanaka Y, Kawaguchi M. Tracheal intubation by trainees does not alter the incidence or duration of postoperative sore throat and hoarseness: a teaching hospital-based propensity score analysis. Br J Anaesth 2015; 115: 463-9. 
11. McHardy FE, Chung F. Postoperative sore throat: cause, prevention, and treatment. Anaesthesia 1999; 54: 444-53.

12. Christensen AM, Willemoes-Larsen H, Lundby L, Jakobsen KB. Postoperative throat complaints after tracheal intubation. Br J Anaesth 1994; 73: 786-7.

13. Higgins PP, Chung F, Mezei G. Postoperative sore throat after ambulatory surgery. Br J Anaesth 2002; 88: $582-4$.

14. Hara K, Maruyama K. Effect of additives in lidocainespray on postoperative sore throat, hoarseness and dysphagia after total intravenous anesthesia. Acta Anaesthesiol Scand 2005; 49: 463-7.

15. Tazeh-Kand NF, Eslami B, Mohammadian K. Inhaled fluticasone propionate reduces postoperative sore throat, cough, and hoarseness. Anesth Analg 2010; 111: 895-8.

16. Orandi A, Orandi A, Najafi A, Hajimohammadi F, Soleimani S, Zahabi S. Post-intubation sore throat and menstruation cycles. Anesth Pain Med 2013; 3: 243-9.

17. Zhao X, Cao X, Li Q. Dexamethasone for the prevention of postoperative sore throat: a systematic review and meta-analysis. J Clin Anesth 2015; 27 : 45 50.

18. Sumathi PA, Shenoy T, Ambareesha M, Krishna HM. Controlled comparison between betamethasone gel and lidocaine jelly applied over tracheal tube to reduce postoperative sore throat, cough, and hoarseness of voice. Br J Anaesth 2008; 100: 215-8.

19. Maruyama K, Sakai H, Miyazawa H, et al. Sore throat and hoarseness after total intravenous anaesthesia. Br J Anaesth 2004; 92: 541-3.

20. Gustavsson L, Vikman I, Nyström C, Engström Å. Sore throat in women after intubation with 6.5 or 7.0 $\mathrm{mm}$ endotracheal tube: a quantitative study. Intensive Crit Care Nurs 2014; 30: 318-24.

21. Hardy F. Postoperative sore throat: cause, prevention and treatment. Anaesthesia 1999; 54: 444-53.

21. El-Boghdadly K, Bailey $\mathrm{CR}$ and Wiles MD. Postoperative sore throat: a systematic review. Anaesthesia 2016; 71: 706-17.

22. Hu B, Bao R, Wang X, et al. The size of endotracheal tube and sore throat after surgery: a systematic review and meta-analysis. PLoS One 2013; 8: e74467. (doi: 10.1371/journal.pone.0074467).

23. Combes X, Schauvliege F, Peyrouset O. Intracuff pressure and tracheal morbidity: influence of filling with saline during nitrous oxide anesthesia. Anesthesiology 2001; 95: 1120-4.

24. Seegobin RD, van Hasselt GL. Endotracheal cuff pressure and tracheal mucosal blood flow: endoscopic study of effects of four large volume cuffs. Br Med J (Clin Res Ed) 1984; 288: 965-8.
25. InousS. Tracheal intubation by trainees does not alter the incidence or duration of postoperative sore throat and hoarseness: a teaching hospital-based propensity score analysis. British J Anaesthesia 2015, 463-9.

26. Melkamu Gemechu B, Gebreegziabher Gebremedhn E. Risk factors for postoperative throat pain after general anaesthesia with endotracheal intubation at the University of Gondar Teaching Hospital, Northwest Ethiopia, 2014. Pan African Medical Journal 2017; 27: 127-132.

27. Bulut H. The effect of cold vapor applied for sore throat in the early postoperative period. J Peri Anesthesia Nursing 2016; 31: 291-7.

28. Jeon Y, Seok Park J, Moon S, Yeo J. Effect of intravenous high dose vitamin $\mathrm{c}$ on postoperative pain and morphine use after laparoscopic colectomy: a randomized controlled trial. Pain Res Manag 2016; 2016: 9147279. (doi: 10.1155/2016/9147279).

29. Kehlet H, Dahl JB, Anaesthesia, surgery, and challenges in postoperative recovery. Lancet 2003; 362: 1921-8.

30. Hasanzadeh Kiabi F, Soleimani A, Habibi MR, Emami Zeydi A. Can vitamin $\mathrm{C}$ be used as an adjuvant for managing postoperative pain? A short literature review. Korean J Pain 2013; 26: 209-10.

31. Majewska MD, Bell JA. Ascorbic acid protects neurons from injury induced by glutamate and NMDA. Neuroreport 1990; 1: 194-6.

32. Majewska M, Bell J, London E.D, Regulation of the NMDA receptor by redox phenomena: inhibitory role of ascorbate. Brain Res 1990; 537: 328-32.

33. Berger M, Vitamin $C$ requirements in parenteral nutrition. Gastroenterology 2009; 137. S70-S78.

34. Carr AC, McCall C. The role of vitamin $C$ in the treatment of pain: new insights. J Transl Med 2017; 15 : 77. (doi: 10.1186/s12967-017-1179-7).

35. Schleicher RL, Carroll MD, Ford ES, Lacher DA. Serum vitamin $\mathrm{C}$ and the prevalence of vitamin $\mathrm{C}$ deficiency in the United States: 2003-2004 National Health and Nutrition Examination Survey (NHANES). Am J Clin Nutr 2009; 90: 1252-63.

36. Fukushima R, Yamazaki E. Vitamin C requirement in surgical patients. Curr Opin Clin Nutr Metab Care 2010; 13: 669-76.

37. Carr AC, Shaw GM, Fowler AA, Natarajan R. Ascorbate-dependent vasopressor synthesis: a rationale for vitamin $\mathrm{C}$ administration in severe sepsis and septic shock? Crit Care 2015; 19: e418.

38. Rebec G, Pierce R, A vitamin as neuromodulator: ascorbate release into the extracellular fluid of the brain regulates dopaminergic and glutamatergic transmission. Prog Neurobiol 1994; 43: 537-65. 
39. Chen S, Roffey DM, Dion CA, Arab A, Wai EK. Effect of perioperative vitamin $\mathrm{c}$ supplementation on postoperative pain and the incidence of chronic regional pain syndrome: a systematic review and metaanalysis. Clin J Pain 2016; 32: 179-85.

40. Khanna NC, Sharma SK. Megadoses of vitamin C prevent the development of tolerance and physical dependence on morphine in mice. Life Sci 1983; 33: 401-4.

41. Talkhooncheh M, Alaei HA, Ramshini E, Shahidani S. The effect of vitamin $\mathrm{C}$ on morphine selfadministration in rats. Adv Biomed Res 2014; 3: 178-80.
42. Zeraati F, Araghchian M, Farjoo MH. Ascorbic Acid interaction with analgesic effect of morphine and tramadol in mice.Anesthesiol Pain Med 2014; 4: e19529-e19534.

43. Rice M. Ascorbate regulation and its neuroprotective role in the brain. Trends Neurosci 2000; 23: 209-16.

44. Willis W, Westlund K. Neuroanatomy of the pain system and of the pathways that modulate pain. Journal of Clinical Neurophysiology 1997; 14: 2-31. 